\title{
Teaching Values in Education as a Political Act for Social Change
}

\author{
Victor J. Pitsoe ${ }^{1}$ and Vimbi P. Mahlangu ${ }^{2}$ \\ ${ }^{1}$ Department of Educational Leadership and Management, College of Education, \\ University of South Africa, South Africa \\ ${ }^{2}$ Department of Education Management and Policy Studies, Faculty of Education, \\ University of Pretoria, South Africa \\ E-mail: ${ }^{1<\text { Pitsovj@unisa.ac.za }>{ }^{2}<\text { Vimbi.mahlangu@up.ac.za }>}$
}

KEYWORDS Social Change. Critical Pedagogy. Change Agents. Reflexive Practice. Democracy

\begin{abstract}
The concept of values education has gained popularity and is amongst one of the fastest growing approaches in the world, supported by policy makers, educationists and governments. It plays a fundamental role in the development of an active citizenry of a country; and encourages adults to model values and to give time for reflective practices that empower individuals to be effective students and good citizens. In line with this, the shift towards the democratic dispensation in South Africa has far reaching implications in the dominant value system. The purpose of this article is to explore the role of the schools in promoting social change. Drawing from critical pedagogy framework and Bourdieu’s Social Reproduction Theory, this article argues that teaching values education, as a political act, can serve to challenge, enforce, or reconstruct societal norms and values.
\end{abstract}

\section{INTRODUCTION}

Values education is one of the fastest growing approaches in the world, supported by policy makers, educationists and governments. Notwithstanding their acknowledgement in the primary role of parents in values formation, values education plays a fundamental role in the development of an active citizenry of a country; and encourages adults to model values and to give time for reflective practices that empower individuals to be effective students and good citizens. At philosophical level, it is a straightforward and radical way to increase responsible behaviour without indoctrination - it is concerned with what we do about those values. Literature notes that values education transcends cultural and religious (for example) differences: it involves raising awareness of fundamental values common to all cultures and religions. In addition, values education enables people to make up their own minds and enables extensive respectful discussion. Hence, a values obsessed population is able to take charge of the many issues facing society, including social problems and political moral decisions, rather than sitting by the sidelines and allowing someone else to do the deciding for them.

Corresponding author:

Victor J Pitsoe
The shift towards the democratic dispensation in South Africa has far reaching implications in dominant value system. For example, in the midst of others, the government is facing the task of transforming its public education system to support the values articulated in its Constitution. This article argues that teaching values education is a political act that can serve to challenge, enforce, or reconstruct societal norms and values. In addition, it sees teachers as change agents who can transform their own lives, students' lives, and communities they serve. Central to this article is the assumption that the teachers who believe in education for social change work to ensure that their students have the tools to be effective advocates for change, and know how to examine multiple viewpoints. Critical pedagogy offers a medium through which teachers can begin to disrupt existing structures that undermine equity in and outside of classrooms, while positioning learners as proactive agents of change. It provides a zone of intersection for social, environmental, political, and personal issues.

The purpose of this article is to explore the role of the schools in promoting social change. If teachers are to be effective in providing their students with opportunities to discover the knowledge necessary to effect social change, then a concerted effort must be made to ensure that education includes democratic and critical pedagogies, multicultural education, 
community-based education, and more specifically, val-ues education. Drawing from critical pedagogy framework and Bourdieu's Social Reproduction Theory, this article (1) explores values educa-tion for social change; (2) argues schools as institutions for social and cultural reproduction;(3) explores teaching values education as prac-tice of democracy; and (4) sketches teaching values education as reflective practice.

\section{Values Education for a Social Change}

The origin of the word in its Latin (valere) and old French (valior) refers to that which is worth striving for. A value is an enduring belief that a specific mode of conduct or end -state of existence is personally or socially preferable to an opposite or converse mode of conduct or end-state of existence (Nieuwenhuis 2007: 9). Values clarification seeks to help students identify their own beliefs. Values education may help students to identify or choose from the following core values, for example, tolerance, love, fairness, freedom, unity, responsibility, respect for life and the truth (Kidder 2009: 85).

Education is never value-free and neutral. Values education, in its generic sense, embraces both ethical and non-ethical values (Bagnall 2007: 72). It is as old as education itself; and is known internationally by a number of names, including moral education, character education, ethics education, citizenship education, religious education and democratic education (Nieuwenhuis 2007: 9; Aspin 2007: 30; Pendlebury and Enslin 2007: 240). Each variant has a slightly different meaning, pointing to one or other distinctive emphasis. In spite of these different meanings, values education still plays a vital role in social change. It shapes morals, mentality, and culture in agreement with the economic class. If South African schools and educators are to take this route, then they must be knowledgeable in how to prepare students to accept social change and make appropriate and positive social changes for the good of society. This article views schools as nascent communities, where teachers, as social reproduction agents, can influence social change and can use behavioral (or misbehavioral) opportunities to help in rebuilding community in the adult world, which students often emulate.

Social change is a concept riddled with ambiguities and contradictions, and it is broadly perceived. It is not a homogeneous process and has both negative and positive dimensions. Several ideas of social change have been developed in various cultures and historical periods. However, aspects in societal change may be summarised under three main headings: economic, political and cultural. Social change refers to any significant alteration over time in behavior patterns and cultural values and norms. For some scholars (Collins 2009; Priestley 2011; Aspin 2007; Pendlebury and Enslin 2007) social change is the alteration of mechanisms within the social structure, characterized by changes in cultural symbols, rules of behaviour, social organizations, or value systems. In its broadest sense, social change is any change in social relations. Viewed this way, it is an ever-present phenomenon in any society. A distinction is sometimes made then between processes of change within the social structure, which serve in part to maintain the structure, and processes that modify the structure (societal change).

Social change is a tune for the postmodern age. Priestley (2011: 1) observes that education systems worldwide mirror this overall trend, with the last 15 years being characterized by what Levin has described as an epidemic of change. Flowing from this observation, the burning questions are, therefore, "how teaching values in education, as a political act, can contribute towards social change" and "how schools can influence social change?”. Education is a social instrument of great importance, and is never autonomous process, separate and apart from the society it serves (Edwards 1951: 39). Quite often, it always develops within a particular social context; and it is anchored in the civilization of which it is a part; in a very real sense, it is the child of historic circumstance. Education always finds its central purpose, its guiding principles, in the particular social order in which it develops and functions.

The role of education as an agent or instrument of social change and social development is widely recognized today (Johnson et al. 2008: 329). Social change may take place - when humans need change. When the existing social system or network of social institutions fails to meet the existing human needs and when new materials suggest better ways of meeting human needs. Literature notes that social change takes place as a response to many types of changes that take place in the social and 
nonsocial environment. For this reason, teaching val-ues education has a potential of initiating social changes by bringing about a change in outlook and attitude of students. It can bring about a change in the pattern of social relationships and thereby it may cause social changes.

In line with this, South Africa's transition from a racist apartheid society to a fully democratic nation calls a values education teaching that is rights-based and underpinned by Dewey's principles. Dewey held that schools are agents for social change. As a progressivist, he argued that if teachers make efforts to find answers about the idea(s) of democracy, then we will be able to better understand and answer the question about how schools contribute to social change. Dewey held that to depend overly on subject knowledge and methods was fatal to the best interests of education. He spoke, rather, of the need for a way of knowing that was about the cultivation of a mindset on the part of teachers that was, at one and the same time, self-reflective and directed towards instilling reflectivity, inquiry and a capacity for moral judiciousness on the part of students (Dewey 1964). On the other hand, this idea was also supported by Jurgen Habermas whose theory of knowing provides a particularly powerful tool for analyzing the capacity of values education to change people's beliefs and behaviours, to make the kind of difference that would seem to be its promise. This change is described by Habermas as "praxis", a practical or communicative action designed to right the wrongs in one's environment.

Flowing from the above background, values education is timely for the South African context as it undergoes a process of reviewing the national curriculum in state schools, and as reshaping of higher education continues to evolve. Education is used to inculcate values and practices where the society is ensuring that continuity is established with the culturally laden past. Hence, schools should be viewed as embryonic communities, where teachers can use behavioral (or misbehavioral) opportunities to help in "rebuilding community in the adult world, which children often emulate. From a democratic perspective, parents and other community members and institutions should see themselves as partners rather than as outsiders. Thus, education constitutes an essential social process that will inevitably attract the attention of social, religious, economic and political interest groups
(Nieuwenhuis 2007: 7). In addition, these groups know that education has a potential to shape the future society, and they are bound to view schools as institutions that can promote their goals.

\section{Schools as Social Institutions for Social and Cultural Reproduction}

Concern with the processes whereby societies and cultures perpetuate themselves has an ancient pedigree, traceable back to Aristotle's analysis of the domestic economy in political orders (Collins 2009: 34). However, in recent years, there has been a growing body of literature suggesting that schools are institutions for social and cultural reproduction. The concept of cultural reproduction was first developed by cultural theorist Pierre Bourdieu in the early 1970s. Social reproduction theory offers a paradigm of class analysis argued to be capable of explaining persistent inequalities in educational stratification despite state efforts at educational expansion cross-nationally (Tzanakis 2011: 760).

According Bourdieu, children from middleclass families are advantaged in gaining educational credentials due to their possession of cultural capital. In this article, we acknowledge that Bourdieu can be criticized for not being precise enough about exactly which of the resources associated with the higher-class home constitute cultural capital, and how this recourse is converted into educational credentials. Capital, in Bourdieu's theory, can be defined as a resource which can have monetary or nonmonaetary forms and also has tangible or nontangible forms. For Tzanakis (2011: 76), cultural capital is assumed to be one of the central familybased endowments whose social class value impacts offspring intergenerational educational probabilities unequally. It assumes central importance in the above process of social reproduction because inequalities in cultural capital reflect inequalities in social class.

Bourdieu's theory of social and cultural reproduction has attracted great attention from sociologists in the English-speaking world since the first translations of his work appeared in the early 1970s (Nash 1990: 431). Furthermore, his anthropologically and historically informed approach to the study of social and cultural reproduction has brought a new sense of coherence to the sociology of education. Bourdieu (1984) 
holds that culture is the language, the categories, and the principles of living; and plays a paramount role in structuring life chances. Thus, cultural reproduction involves the transmission of existing cultural values and norms from generation to generation. On the other hand, social reproduction theories are fueled by the central question of how and why relationships of inequality and domination are reproduced. The social reproduction theory maintains that the existing class structure and social inequalities of individuals in a capitalist society are reproduced by that society; and it argues that schools are not institutions of equal opportunity but mechanisms for perpetuating social inequalities. While theories of social reproduction may, perhaps, proffer a basis for understanding how and why inequalities are reproduced, they do not necessarily provide any immediate solutions that could potentially help put an end to, or alleviate the reproduction and perpetuation of the vicious cycle of inequality that persists in schools (Macris 2009). If these theories are to be of any importance, they must allow us to raise practical questions that will serve to guide educational policy action.

The society has its institutions through which it reproduces itself: family, economy, government, religion, and education. All institutions are meant to socialize its members. From a social reproduction theory stance, educational institutions follow the directions of dominant group to maintain the status quo of the society, that is, the lower, middle and upper class children become lower, middle and upper class adults respectively. This is a cyclic process as the dominant group roots the values, and aims favouring themselves in educational institutions. Dominant group also promotes the myth through other institution like government, economy that education is for all and provides a means of achieving wealth and status. In a nutshell, the social reproduction framework sees the true function of the schools as preparing students to assume a job in the same socio-economic status as the dominant social classes.

Recent empirical evidence has shown that the main site that theories of reproduction focus on is the school. One of Bourdieu's best known theses is of the school as a conservative force. This has, however, given rise to a misconception for Bourdieu does not, in fact, argue that the school is merely a passive instrument for the reproduction of family acquired habitus which "objectively" certifies the dominant cultural code of society (Nash 1990: 435). Bourdieu's investigation of the connection between the school and systems of thought situates the school, in non-traditional societies, as the central generative site of the distinctive habitus of the culture. Hence, Bourdieu (1971: 192-193) note that it may be assumed that every individual owes to the type of schooling he/she has received a set of basic, deeply interiorised master patterns. As a result, in this theory, schooling does have its own power to shape consciousness, over and above the power of the family, and it is clear that the role of the school is acknowledged as active and not merely passive in its "legitimation" of family acquired habitus (Bourdies 1971).

Education always finds its central purpose, its guiding principles, in the particular social order in which it develops and functions (Edwards 1951: 394). Stambach (2012: 324) notes that education is a language and repertoire of social practices through which families, students, and educators themselves re-make their own class-consciousness, largely through their complicit participation in the mechanics of the system. From a critical pedagogical perspective, education is a key site of cultural production and social reproduction. It is not as a pre-given container or universal and unchanging category of social relations and life-worlds, but as a complex terrain and outcome of discursive, material and institutionalised struggles over the role of education in the social contract. Within a social reproduction framework, education provides the necessary skills for production, the necessary graded ideologies for the social division of labour, and necessary milieu for the actual formation of subjectivities through the celebrated "imaginary relationships of individuals to their real conditions of their existence” (Willis 1981; Hall 1980). Snoook (2007: 80) notes that schools in democratic societies have been traditionally expected to reinforce the basic values of these societies to initiate young people into traditions of critical thought.

In the light of the above, teachers can be regarded as potential agents of change, for good or for ill, in any society. Schools have a pivotal role of influencing social change. Bourdieu's theory about the role of schools and teachers in the transmission of intergenerational inequali- 
ties rests on a number of assumptions about the teacher population and the school context. The role of the school is to promote arbitrary cultural values via teachers (Tzanakis 2011: 81). Teacher assessments of students however are argued to reflect not only aptitude and performance in students, but also work habits, basic communicative and other non-cognitive skills.

\section{Teaching Values Education as Practice of Democracy}

A plethora of literature (Dewey 1932, 1943, 1946; Kneller 1967; Steiner 2004; Aspin 2007; Narvaez 2007; Bagnall 2007; Tudball 2007; Masolo 2010) suggests that educational theorists and philosophers agree that philosophical values are at the root of a philosophy of education and that curriculum theory and educational policy choices usually follow the philosophical values. For example, Dewey (1943) held that to depend overly on subject knowledge and methods was fatal to the best interests of education. He argued that (1) the values of the school are a reflection of the society and that (2) the values are relative to the social situation of the country. He contended that (3) the "higher" values of democracy would eventually come to be held on a wide-spread basis by rational people.

This article acknowledges critics' contention that democracy is the worst form of government except all the others that have been tried. However, it departs on a constricted political notion of democracy which includes the following features: (1) the accountability of rulers through regularized multi-party, free and competitive elections; (2) political institution and policies which reflect societal values as established and changed via formal electoral and legislative mechanism; (3) the freedom to associate and organise politically; and the rule of law (Sifuna 2000: 215). Notwithstanding the violation of basic individual rights and authoritarianism by the apartheid regime, this article argues that democracy, in all of its historic and contemporary forms, has played a pivotal role in shaping conceptions of public education.

The second and perhaps more profound reason for the clamor for democracy is the classic contributors to modern political thought and commentary, as well as those who framed modern arguments, have dealt specifically with the educational necessities of establishing and main- taining a democratic polity. They have generally reflected on the tensions between the socialization of a democratic nation's subjects (that is, as acculturated, law abiding members) and the education of its citizens (that is, critically thinking, active participants). Values education is concerned with the promotion of values - moral, social, political, aesthetic - as vital elements in progammes of education for future life (Aspin 2007: 30). Hence, the call for values education is a policy imperative. For example, the then Minister of Education, Kader Asmal MP, requested in February 2000 the formation of a working group on values in education and, after a process of research and debate, the presentation of a formal report of findings and recommendations (DoE 2000). The report makes an argument for the promotion of the values of equity, tolerance, multilingualism, openness, accountability and social honour in the South African schools. It also defines the moral aspirations of South African democracy as defined in the South African Constitution and Bill of Rights. This choice of values is framed by three considerations of educational philosophy.

Like political institution, education is hopefully moving towards a broader democracy in which each person is free to develop his interests and abilities (Stewart 1975: 159). Herein, he contends, rests the enigma with which teachers are now faced: maintaining order consistent with the democratic values. Democracy is intelligent moral action practiced in a community that strives to maximize human development, insure and diffuse freedom, and create positive peace built on the presence of goodwill rather than on the absence of fighting (Stewart 1975: 160). Of primary importance is how to live and practice the constitutional values. This article finds it rather senseless to talk to the students about democracy, tolerance, equality, and similar values if the teachers cannot practice them in action. By showing respect to each other and to the students, for example, could help the students gradually to learn true meaning of respect. A teacher cannot talk about democracy, a teacher must be democratic to help the students to be democratic (Stewart 1975: 160).

Moral development occurs through a sequence of universal stages. Although it has been commonly assumed that moral values and beliefs are acquired through some process of cultural transmission, or of identification with 
the beliefs and values of parents and members of adult society, the research of Kohlberg and his associates indicate that children pass through an invariant sequence of stages of reasoning about values and beliefs, and the modes, or any way of moral reasoning is as important in understanding moral behavior as the content of the beliefs themselves. The moral fibre and value systems of our people are constituted and reconstituted in our schools, in our places of worship, on the sports fields and at the workplace. Many other institutions and factors will influence and shape the development of our value systems, but all will agree that our schools, colleges, learning centres and institutions of higher learning have an extremely important role to play in supporting the development of our value system and in establishing the regeneration of the ethical fibre of our society (DoE 2000b: 2).

There is a long tradition of viewing democracy and education as inseparably interconnected: democracy as a basic value and practice in education; and education as a means to strengthen and sustain democracy. Democracy was a central theme for major educational thinkers of the last century, such as John Dewey, Paulo Freire and Loris Malaguzzi. In terms of the development of thinking about education for democracy in the twentieth century, it is the figure of John Dewey that towers above all. For education to be successful as an agent of social change, among others, it must include a focus on democratic education, solution-focused critical pedagogy, popular and community-based education, and multicultural education. At classroom level, the shift challenges teachers to be accountable for the change that takes place in students. This stems from the assumption that their words and actions trigger positive behavioural and attitudinal changes in learners. Nevertheless teachers' task as change agents is not limited to the school setting and their students. In the disadvantaged communities, where literacy rate is low and people are not aware of their rights and responsibilities, lack ideas on good health habits, local teachers can act as change agents. From a critical pedagogy perspective, teachers as cultural workers can cause change to take place in the community settings.

Against the above background, democracy and teaching values education should not be perceived as separate silos - schools can influ- ence social change. We hold that teaching values education has a great potential of improving and refining the practice of democracy. Values education should be derived from their principles, for example, when teaching about justice the school itself must have complied by not discriminating on the basis of irrelevant differences such as colour, race, creed, gender, and equality of opportunities (Nieuwenhuis 2007: 17). Both concepts are inseparably interconnected. Democracy may be reinforced by primary education encouraging democratic attitudes. Its practice needs certain values to be shared among the community of the early childhood institution. This notion is supported by Dewey (2001: 341) who points out that democracy involves freedom and voluntary choice which brings together the individual and society. In line with this, values education, as tool for social change, becomes a valuable tool for helping to bring about democratic values and behaviours. In the South African context, the democritisation of schools, among others, is aimed at fostering a democratic culture in a wider society. The continuing clamor for the teaching of values education should be seen as redemption. Hence, values education instruction and practice are essential for advancing towards democracy, improved governance and social transformation.

\section{Teaching Values Education as Reflexive Practice}

The concept, "reflexive practice", is very broad and carries diverse meanings. Along this continuum, there are many interpretations with a common thread linking them - namely applying one's experience to oneself, while reflecting upon it, examining it critically, and exploring it analytically. It is seen as an attitude of attending systematically to the context of knowledge construction, especially with regard to the researcher, and at every step of the research process. For some scholars it is a concept used in the social sciences to explore and deal with the relationship between the researcher and the object of his/her research (Brannick and Coghlan 2007: 60 ). From a critical pedagogy stance, the role of teacher is to empower students to participate effectively in both the organizations and communities in which they reside. To achieve this goal we embrace a framework of critical reflexive practice which suggests both the sense of 
questioning, as in "critical thinking," as well as in the sense of critical theory - unmasking hidden ten-sions and meanings with a goal of emancipating thinking and action. By reflexive, this article sug-gests an awareness of and questioning of one's own assumptions and constructions of reality of the societal values. This framework embodies three underlying principles. The first is that knowledge is both socially constructed and com-peting. As teachers, we want students to "ques-tion assumptions and taken-for-granted actions, think about where/who [they] are and would like to be, challenge conceptions of reality, and explore new possibilities”.

Reflexivity is almost meta-reflection, that is, reflecting on the consequences of reflection, which may include action (in terms of a change in our therapeutic process, for example) or inaction and is situated within the sociological concepts of reflexivity. It is necessary to appreciate that reflexive practice operates with reflection as its fulcrum (Roebuck 2007). In addition, reflection is widely recognised in the literature as a useful learning activity for students and practising professionals across many disciplines. A reflection in a mirror is an exact replica of what is in front of it. Reflection in professional practice, however, gives back not what it is, but what might be, an improvement on the original (Roebuck 2007). On the other hand, reflexivity in research design affords one the "space" to decolonise Western research methodologies and challenges us to take ownership of our shortcomings, misunderstandings, oversights and mistakes, to reclaim our lives and to bring about strong changes to our current realities. Being reflexive ensures that we do not compromise our identity whilst undertaking research (Karen and Booran 2003: 212). Reflexivity may engage the process of questioning the enlightenment/modernist prioritisation of reflectivity; erasing it at the same time as acknowledging its pulsing course through the veins of metaphysical enquiry in the present.

From an historical point of view, the principle of reflexivity was first enunciated by William Thomas in the early 1900s. He maintained that the situations that men define as true actually become true for them. By the 1980s, reflexivity was interpreted in terms of mapping research activities against a linguistic background. The researcher was still invisible and there was no analysis of the interaction between the two frames of meaning production. In 1971, Alvin Gouldner pointed out how ethnographers could be regarded as normalising cultural fields - a criticism that threatened to reveal the interests behind Western constructions of knowledge and, resultantly, destabilise the dominant world-view. Its proponents, amongst others, include Bourdieu, Woolgar, Foucault and Bhabha. Bourdieu argued that the social scientist was inherently laden with bias, and only by becoming reflexively aware of such bias, could social scientists free themselves from it and aspire to practising an objective science. For him, reflexivity is an epistemological principle that advises sociologists, as "objectifying subjects", to turn their objectifying gaze upon themselves and become aware of the hidden assumptions that structure their research (Frangie 2009). In addition, he held that reflexivity is part of the solution, not the problem.

The importance of reflexive practice has been attracting increasing attention from a variety of academic disciplines and from researchers whose theoretical convictions range from realism to post-modernism. However, teacher education has not run away from this trend. With the growing influence of post-modernism and post-structuralism on teacher education theory and practice, reflexivity is considered by many supporters to be an excellent phenomenon, as it involves recognition of the problematic nature of research, the dubious position of the researcher, the crisis of representation, the constructive nature of language, as well as an admission of the fact that there is no "one best way" of conducting either theoretical or empirical work (Denzin and Lincoln 2003).

Bourdieu consistently argued that his conception of epistemic reflexivity provided, not only a means of developing richer descriptions of the social world, but also the basis for a more practically adequate and epistemologically secure social science. Bourdieu's reflexivity takes two forms, namely methodological and epistemic. Epistemic reflexivity focuses on researchers' belief systems and is a process aimed at analysing and challenging meta-theoretical assumptions. Methodological reflexivity is concerned with the monitoring of the behavioural impact on the research setting as a result of conducting the research (Brannick and Coghlan 2007: 60). Flowing from this, Bourdieu's reflexivity seems to be essentially a methodology that may 
produce the ironic outcome that a theory, essential-ly of social reproduction, may not be able to reproduce itself. For Bourdieu, reflexivity does not mean that one reflects upon one's theories, but rather on one's practices. It is an attempt to relate social experiences to theoretical constructs.

Of note is the fact that experiences are situated in time and place, and experiences are contextualised (St. Clair et al. 2005: 142). The notion of the teacher as a reflexive practitioner, and the teacher as a researcher of own classroom practice, is widely promoted in teacher education literature of recent years. This involves using reflexive practice as a teacher development tool - both in a pre-service/novice and in an in-service context of professional teacher development. Being reflexive means much more than being critical of a field or aspect/component of teaching practice. It means that one must know how the field is organised and how it is practised (St. Clair et al. 2005: 146).

Flowing from the above, reflexivity should be perceived as a meaningful way of approaching the discipline of learning about teaching values education so that a better understanding of teaching, as well as teaching about teaching might be developed. For reflexivity to lead to valuable learning outcomes, both for teacher and their students should be an effective reflexivity practice. In addition, reflexive practice should be seen by many teachers to be at the very heart of effective teaching values education preparation programmes and the development of professional competence. Teachers cannot be reflexive without reflecting on the modes of teaching and learning involvement. Therefore, reflexive practices can be viewed as essential in accounting for various subjective preconceptions and distortions that infiltrate the decision-making process. Reflexivity is often assumed to be the means through which the assumptions and social values may be uncovered.

\section{CONCLUSION}

The shift towards the democratic dispensation in the South Africa has far reaching implications in the dominant value system. Amongst others, it calls for the schools to promote democratic values. These democratic values amongst others are equality, justice (fairness, equality, and impartiality), freedom, respect for human dignity, non-violence to ensure the freedom and security of the person, truthfulness. The democratic transformation of society is both a policy imperative and a legal obligation. With the increasing violence, moral bankruptcy and moral degradation the South African society, and their schools have a responsibility in developing democratic virtues. For this reason, teaching values education, as tool for social change, has a potential in helping to bring about democratic values and behaviours. Schools, as institutions of social reproduction, have a pivotal role of influencing social change.

\section{REFERENCES}

Aspin DN 2007. The ontology of values education. In: D N Aspin, J D Chapman (Eds.): Values Education and Lifelong Learning: Principles, Policies, Programmes. Dordrecht: Springer, pp. 27-47.

Bagnall RG 2007. The ethics of lifelong learning and its implications for values education. In: D N Aspin, J D Chapman (Eds.): Values Education and Lifelong Learning: Principles, Policies, Programmes. Dordrecht: Springer, pp.61-78.

Bourdieu P 1984. Distinction: A Social Critique of the Judgement of Taste. Cambridge, MA: Harvard University Press.

Bourdieu P, Passeron JC 1990. Reproduction in Education, Society, and Culture.Sage Publications: London.

Bourdieu P 1988. Homo Academicus. California: Stanford University Press.

Bourdieu P 1990. The Logic of Practice. Stanford University Press. California.

Brannick T, Coghlan D 2007. In defense of being "Native": The case for insider academic research. Organizational Research Methods, 10(1): 59-74.

Collins J 2009. Social reproduction in classrooms and schools. The Annual Review of Anthropology, 38: 33-48.

Denzin NK, Lincoln YS 2003. Collecting and Interpreting Qualitative Research. California Thousand Oaks: Sage Productions.

Dewey J 1932. Ethics. Boston: Henry Holt.

Dewey J 1943. The School and Society. Chicago: Univ. of Chicago Press.

Dewey J 1946. Philosophy of Education. Paterson, NJ: Littlefield Press.

Dewey J 1964. John Dewey on Education: Selected Writings. New York: Modern Library.

Dewey J 2001. Education and social change. In: F Schultz (Ed.): SOURCES: Notable Selections in Education. New York: McGraw Hill Dushkin, pp. 333341 .

DoE 2000a. Values, Education and Democracy - Report of the Working Group on Values in Education. Department of Education, South Africa.

DoE 2000b. Values, Education and Democracy. Department of Education, South Africa.

Edwards E 1951. Education as a social instrument. The School Review, 59(7): 394-402. 
Frangie S 2009. Bourdieu's reflexive politics socio-analysis, biography and self-creation. European Journal of Social Theory, 12(2): 213-229.

Hall S 1980. Cultural studies: Two paradigms. Media, Culture and Society, 2: 57-72.

Johnson JA, Musial D, Hall GE, Gollnick DM, Dupuis V 2008. Foundations of American Education: Perspectives on Education in a Changing World. Boston: Pearson Educational.

Karen M, Booran M 2003. Ways of knowing, being and doing: A theoretical framework and methods for indigenous and indigenist research. Journal of Australian Studies, 27(76): 203-214.

Kidder RM 2009. How Good People Make Tough Choices: Resolving the Dilemma of Ethical Living. New York: Harper Collins Publishers.

Kneller G 1967. Foundations of Education. New York: Wiley.

Macris V 2009. The ideological conditions of social reproduction. Canada Journal for Critical Education Policy Studies, 9(1): 20-46.

Masolo DA 2010. Self and Community in a Changing World. Indiana: Indiana University Press.

Moss P 2011. Democracy as First Practice in Early Childhood Education and Care. Encyclopedia on Early Childhood Development. Centre of Excellence for Early Childhood Development. University of London, United Kingdom.

Narvaez D 2007. How cognitive and neurobiological sciences inform values education for creatures like us. In: DN Aspin, JD Chapman (Eds.): Values Education and Lifelong Learning: Principles, Policies, Programmes. Dordrecht: Springer, pp. 127-159.

Nash R 1990. Bourdieu on education and social and cultural reproduction. British Journal of Sociology of Education, 11(4): 431-447.

Nieuwenhuis J 2007. Growing Human Rights and Values in Education. Pretoria: Van Schaik Publishers.

Priestley M 2011. Schools, teachers, and curriculum change: A balancing act? Journal of Educational Change, 12(1): 1-23.
Roebuck J 2007. Reflexive practice: To enhance student learning. Journal of Learning Design, 2(1):7791.

Pendlebury S, Enslin P 2007. "What kinds of people are we?" Values education after apartheid. In: DN Aspin, JD Chapman (Eds.): Values Education and Lifelong Learning: Principles, Policies, Programmes. Dordrecht: Springer, pp. 238-254.

Sifuna DN 2000. Education for democracy and human rights. Africa Development, XXV(1 and 2): 213239.

Snook I 2007. Values in education context. In: DN Aspin, JD Chapman (Eds.): Values Education and Lifelong Learning: Principles, Policies, Programmes. Dordrecht: Springer, pp. 80-92.

St. Clair RN, Rodriguez WE, Nelson C. 2005. Habitus and communication theory. Intercultural Сommunication Studies, XIV(10): 136-150.

Stambach A 2012. Rethinking culture and education. British Journal of Sociology of Education, 33(2): 323-333.

Steiner R 2004. Human Values in Education. Great Barrington: Anthroposophic Press.

Stewart JS 1975. The school as a just community: Transactional development moral education. In: J Meyer, B Burnham, J Cholvat (Eds.): Values Education: Theory/Practice/Problems/Prospects. Ontario: Wilfrid Laurier University Press, pp. 21-74.

Tudball L 2007. Whole school approaches to values education: Models of practice in Australian schools. In: DN Aspin, JD Chapman (Eds.): Values Education and Lifelong Learning: Principles, Policies, Programmes. Dordrecht: Springer, pp. 395-410.

Tzanakis M 2011. Bourdieu's social reproduction thesis and the role of cultural capital in educational attainment: A critical review of key empirical studies. Educate, 11(1): 76-90.

Willis P 1981. Cultural production is different from cultural reproduction is different from social reproduction is different from reproduction. Interchange, 12(2-3): 48-67. 